\title{
Principles of Civil Liability Arising from Bodily Injuries in Iranian and English Law
}

\author{
Dr. Majid Sarbazian ${ }^{1}$, Mehdi Sokhanvar ${ }^{2} \&$ Abedin Rahimi Pordanjani ${ }^{3}$ \\ ${ }^{1}$ Assistant Professor, Faculty of Law and Political Science, University of Shiraz, Iran \\ ${ }^{2} \mathrm{Ph}$.D. student of private law, University of Shiraz, Iran \\ ${ }^{3}$ MA in private law, Qom University, Iran \\ Correspondence: Dr. Majid Sarbazian, Assistant Professor, Faculty of Law and Political Science, University of \\ Shiraz, Iran. E-mail: sarbazian20@gmail.com
}

Received: July 3, 2017

Accepted: September 14, 2017

Online Published: September 20, 2017

doi:10.5539/jpl.v10n5p8

URL: https://doi.org/10.5539/jpl.v10n5p8

\begin{abstract}
Explaining the principles of civil liability in cases that someone injured bodily is now one of the most important issues of law. In fact, in these cases, the question is why someone should compensate other damage? While has not been violated of the contract. If doing the action is allowed, and the subject has the legal authority to do it or fault or bad intention does not occur from him, can be imagined again a responsibility for him? In this regard, civil and criminal liability separate from each other and each is analyzed separately. Foundations of theoretical, practical, legal and in addition to these, in our rights jurisprudence foundations have been added to the former cases. Each of these has sub sets, and each tried to explain that when someone injured bodily the other, why and how to compensate? Who should compensate? To compensate, what must be proved? And of course, in similar cases, results are obtained that each has minor and sometimes major differences. Now, the theoretical foundations (fault, risk, etc.) are accepted and analyzed in Iranian law and in English law, but absolutely none of them have gone towards one of the comments.
\end{abstract}

Keywords: principles, fault, risk, bodily injuries

\section{Introduction}

In Iranian law, since the law of civil liability was passed in 1960, almost explicitly it selected fault foundation of for law of our compensation. The discussion was about principles of the law of civil liability and away from jurisprudence and it was tended to Western law particularly France. Finally, it can be argued that the discussions that exist on the principles of the law of civil liability and compensation law are theoretical arguments that have been taken more from French law practical arguments that have been taken from jurisprudence.

The question is that in non-contractual civil liability, why should one person against another condemned to compensate the while not have contract and agreement with him and in addition may even not be harmful and only is the supervisor or employer or the owner of the animal and in other words, the problem is what is the reason that law has considered him responsible against another? Has the law considered someone responsible that the fault occurs from him or not, what is important is his profit although not do the fault or another reason exists that the law considers him responsible? In this way, lawyers have been divided into several groups and each group knew a basis for it. Most lawyers believe that the principle of civil liability is one of the three theories: Fault, risk and guarantee the right. Although there are other theories that are poorly known and not accepted by legislators. "The study of law history shows that in the first, various forms of liability had not been separated and there was no clear boundary between civil and criminal liability, since separating the two responsibilities, in civil liability, it was paid attention for compensation, regardless of its principle. In recent centuries, especially from the 18th century in European countries, especially France, the lawyers tried to analyze issues and provide right legalright solutions. "(Soltaninejad, 2001).

"There are no theoretical issues principally in English law, in other words, theoretical issues are investigated less. Lawyers of the country on issues related to the principals of civil liability investigate issues that are different from issues that in legal systems such as Iran and France are investigated. This feature is common among all countries that have the legal system of common law. In the country (s), issues are analyzed that are useful and in 
other words, what happens in practice is investigated and not as our lawyers to be mainly theorist and while studying theories, in cases that are necessary to be referred to rules and regulations as an impact that theories have. Issues that are investigated in law principle of civil liability in common law are principal whether fault or error occurs from someone who's the defendant of dispute? Is there a duty of care? Whether the breach of duty, the damage is incurred, and a causal relationship exists between it and damage? (Rahimi Pordanjani, 2013) "Even a group of writers say: "probably due to the influence of translations of Islamic religious books in in the early nineteenth century, civil liability in the UK legal system based on Islamic thought is built. Iran's legal analysis unlike analysis of some experts, regarding scientific and failure to pay particular attention to the fault is like to common law rights to French law, although in practice these systems reach to a result of "the responsibility of loss factor in most cases." For example, in Iranian law about the property in the possession of possessor, the first problem is that he must to return property and If not did such action, he is liable for paying the damage, whether his is guilty or not ...If we analyze the practical similarity of safe and irresponsibility in Islamic law and discussion of duty in common law and objective interpretations of the fault in France we find that finally, the result of all systems will be unique.". This system is based more on legal cases. Investigating foundations can have the role in view of judges to new cases and analysis of the former votes and help them in finding new ways, in other words, in the legal system, foundation affects the judicial decision and on the basis judgment, think about new views and apply them in cases. (Hekmatnia, 2010) It should be noted that the phrase told not means that theoretical discussions in English law are absolutely not raised, but these ideas have been existed for a very long time and even in some areas severely affected, (so that today it is believed that the common law is more affected by the fault theory).

\section{Principles of Compensation of Bodily Injuries in Iranian and Islam Law}

\subsection{Rule of Prohibition of Detriment}

The principle that the damage to be compensated always is existed as one of the axioms from very long pasts in all nations until now as an independent branch of law are discussed and been investigated to the extent that even we can say the principle that the damage to others should be compensated, the advance form of it is the law of civil liability and the cause of its independence and development has been this that the discussion of damage compensation is not as former simple mode and the period of compensation for private damages is when that is late (private vengeance) and people are not allowed to compensate damage against the killing and bodily injury personally otherwise by law will be reprimanded and even compensation of other part. In this way there no exception and the only thing that there is about this is that parents of deceased person can revenge the murderer with conditions, and even this right is only about a murder that has been proven, but without any causes to remain for law enforcement, he acts to kill the murderer himself. ${ }^{1}$

The rule of "prohibition of detriment" is one the most famous of legal rules that in all fields of law, from the worships to transactions argued and in many issues; it is the only evidence to prove sentence (Makarem Shirazi, 2011). Rule of the prohibition of the detriment that is derived of the hadith of the Prophet, "prohibition of detriment in Islam" from various directions was discussed but let's see if we can consider the rule of prohibition of the detriment as one of the legal foundations of civil liability? In this case, there is consensus among scholars because some jurists know the term (prohibition of detriment) in the meaning that there is no detriment in Islam and fact the lawmaker (subject) has denied the detriment, in fact, deny the demand (commandment), and thereby the jurists believe that the detriments that not have certain title must be compensated from the public fund.

On the contrary, some believe that the rule of prohibition of the detriment as a matter of customary and rational is accepted and in some cases, there is a detriment decision, in fact, the detriment is compensated, and a detriment that is compensated should not be considered a detriment. (Amid Zanjani, 2003). In fact, they believe that it should be compensated for all damage and rule of prohibition of the detriment for detriments that are not compensated for any reason are considered the causes of liability because the sanction of detriment means sanction of continuation obtained of detriments and this requires removal of harm and compensation of damage. (ibid).

It is better to be investigated the concept of detriment in the rule of prohibition of detriment to be specified that what kind of detriment is meant. Is there financial detriment in properties or it can be used on bodily injuries. Previously concepts such as "detriment" and "damage" were explained that it is understood from them that detriment means losing something that belongs to man. Hence it does not matter what man has lost is his property or part of the body or with conditions of preventing the emergence of future and it is required the

${ }^{1}$ Article 219 of former IPC and Article 420 of the new IPC 
detriment to be such material and visible, but the reputational damages are also considered spiritual detriment. (The feature of the rule that in all cases said in common is that in any case, damage, for example, imported injury to innocent people is compensated, whether the agent has the intention of the objection of damage or not.

So, rule of prohibition of detriment because of the higher position and oversight over all other legal and judicial rulings has a unique importance in particular in civil liability (Deilami, 2010) and, therefore, certainly one of its applications is ruling on compensation for damages resulting from bodily injuries and so, anyone who defects or cut or paralyze member of one's body, or causes any bodily injuries upon him, he must compensate the detriment and basically blood money is based on the rule of prohibition of detriment and "means" of its run.

\subsection{Rule of Wasting}

After the rule of prohibition of detriment, the rule of wasting is the most important rule in compensation. Although the term of this rule is, "Man Atlaf Mal Al-Gheir Fahu AL Zaman" but does not allocated to compensate the damage caused by the waste of property, but even scholars in discussions about compensation for physical damages and payment of blood money have named it, so the jurists say the issue is that waste is allocated to specific cases on which the warrant is liability and also in cases other than mortgage and rent and like it, because when it is stated in the infallible Word that "Everyone causes detriment" or even certainly can be said that the sentence is not special for these cases (ie financial instances) so wasting is the overall cause of liability (Fahimi, 2011). A clear example can be considered the responsibility for compensation by a doctor (Najafi, 2006).

In law, the rule of wasting and causation are discussed separately and for each separate argument has been raised, including:

1) "Faman Atadi Alaykom Fatadu Alehe Bemasale Ma Atadi Alaykom" (Baqarah, verse 194). This verse primarily refers to the death, but violence as mentioned in this verse does not mean liability but means retaliate in cases of assaults and bodily injuries, but the answer is that violence in this verse is general and in the physical damage and financial loss can be used (Farahi, 1430). However, this verse is the most important verse that in the rule of wasting is cited.

2) "And Jaza Sia Sia Masalaha." (Shura', verse 40). Scholar's base on the rule of wasting referred to this verse and considered it from the grounds of liability and compensation, and certainly, in this case, there is no difference that oppresses and injury of a human is oppression and damage of property or physical injury and the body and soul.

3) "... Harama Mala [Muslim] Kahrama Dama", this narration has considered the sanctity of property as blood sanctity, ie, primarily the sanctity of soul and body is considered higher than property and then analogized the sanctity of property to it and considered close to the sanctity of self. The narration that among all Islamic sects is trusted states in this regard, everyone that wastes the other property, regarding of case, i.e. paying price is guaranteed. As if injuries to an innocent man, it means he is guaranteed for murder or mutilation and bodily injury and must pay for retaliation or blood money.

\subsection{Rule of Causation}

This rule is the one of juridical foundations in the field of civil liability. In the following, there are two hadith that are including traditions of evidence of this rule:

1) In Sahih Zarareh from Abu Abdullah, Imam Sadiq (AS) narrated that was said to Imam: If someone digs a well in property and someone passes there and fall into it, what is the ruling? ${ }^{5} \mathrm{He}$ said: he is the guarantor because digging well in the other property (other than its property) is guarantee for any losses (Mousavi Boujnordi. 2008).

2) In Moseghe Samae that asked Imam Sadiq (AS) if anyone dig a well in his property what is the ruling? Imam said: For what he digs in his property, he is not guaranteed, but if otherwise, he is guarantee. (ibid).

About this whether this rule can be cited from principles of civil liability on compensation resulting from bodily injuries, it must be said that this rule not allocated to financial loss to another especially in the first hadith, Imam considers the digger of well in charge of the compensation of body of a person who has fallen into a well.

In addition to the juridical foundations described, based on the hadith of the Prophet "Kalkom Ra and Kalkom Masul" that is a rule of Islamic morality, it can be raised a total principle called "Takaful Rule" that according to which individuals against each other have mutual responsibility. The rule that governing responsibility and social guarantee and including individual responsibilities can be the basis of the rule of law of civil liability. This principle is the basis and reasons that are cited in the compensation of financial, physical damages and extra 
damages on blood money.

It is said that cause has different uses in jurisprudence, that sometimes it is used against perpetrator, and sometimes in its general sense and sometimes in the front of crimes and the compensation of bodily injuries, its recent meaning is purpose in which criminally is responsible for the damage and blood money not kinsman (Marashi. 1991).

\subsection{The Theory of Fault ${ }^{2}$}

According to this theory, only one will be accountable and responsible against another who committed the fault. In other words, it means that to be able to find a causality relation between the damage to a person and his fault and to be able to say that the damage caused by the behavior contrary to law or regulation. Accordingly, the person who causes loss only when is obliged to compensate that a fault to be happened from him but it is not all, but at a later stage, the injured party must be able to prove that fault on his part caused the damage, i.e. be able to prove the causal relationship. The cause that this theory has been called fault is that hear the principle is that no one makes fault and in other words, the principle is on lack of fault, and the claimant (damaged) must prove that the defendant makes fault that damages reached him because talks contrary to the principle.

About this that what is the basis of liability in Iranian law is, there is unity but the view of most writers is that the fault is the base but not in absolute but also as a principle is accepted and liability without fault only in cases stipulated in the law and as an exception has been accepted. Followers refer to Article one of civil liability law enacted in 1960. According to the article "Anyone who deliberately or as a result of carelessness or without legal authorization damages to life or health or property or freedom or dignity or business reputation or to any other right which has been established by law for people that causes moral or material loss is the responsible for compensation arising from their action. "In other words, in Iran as well as some legal systems, fault is accepted as the main basis for civil liability and perhaps cannot be found a country that fault is accepted as the only basis for liability. In civil liability legislation passed in 1960, the theory of fault has had a much effect.

\subsection{The Basis of Liability in English Law}

It is true that the country's system is based on juridical procedure, but here after issuing verdict on any subject, the former verdict is known as a general principle that other judges will follow it and even exceed it is done difficultly. On the other hand, however, it was said earlier that the common law contrary to the Romano-Germanic more not to views but what happens in practice are, but of the rules and regulations as well as the material that in this section will be told, can be easily understood that the former condition not largely implemented and is adjusted and closed to the writing system. The importance of investigating civil liability caused by these damages is due to provide a special criterion for the determination of the responsible of loss and responsible for the compensation respectively. So we investigate this issue that who was the history of this country? Whether the known foundation in the law of civil liability and contract law is the same? What foundation is there in the past and present? Whether can choose a foundation as the principle? Finally we investigate that responsibility is under the general rule or with specific rule.

In the past, the principle was this that civil liability and compensation is not based on fault. In other words, in most cases, liability was without fault, until in the nineteenth century, the responsibility was on the basis of fault. In other words, historically in English law (and generally in common law) as France law and many other countries, liability without fault is preferred on liability based on fault, so that in the past, in most cases compensation for losses is the only requirement of the responsibilities and is not considered to the mental element of person who causes loss. (Ghasemzadeh, 2004). Then in mid-nineteenth century until the mid-twentieth century, the principle of fault was preferred on the principles of other and the base of the order was related to compensation. However, in the first half of the twentieth century, the principle of workers' compensation changes from the principle of fault to the principle of strict liability. Another major change happened in the years after 1950, and it was the adoption of the universal principle of strict liability in industrial and commercial products. Implementation of the principle of fault in bodily injuries resulting from road traffic accidents became ineffective with law enforcement of faultless responsibility in minor and ineffective in some cases, though that today is not such this (Katuziyan, 1998)

\section{Liability Based on Fault}

Common law is affected by the theory of fault. In English law (as well as in the American law) in the second half of the nineteenth century, lawyers were more in favor of this that fault is the basis of liability. The group, which

\footnotetext{
${ }^{2}$ Fault. Culpability. Negligence. Offense. Blamed. Guilty. Short coming transgression
} 
comprised the majority, believed that liability would not be created without fault. "William Praser ... writes:" ... with the development of moral conscience in the community, this general trend also emerged that legal responsibility should result in behavior that is not expected of a good citizen. This tendency is so strong that prompted the authors to establish the theory of liability on the principle that no liability shall be created without fault (Katuziyan, 2011).

In English law from 1875, the basis of liability was towards fault theory. In this year, the dispute of «Holmes v. Mather » happened, and in driving accidents, the vote of «Bramwell »about the need for proving fault is considered and still seemingly liability arising from driving is based on fault, but this is formal and is closer to the strict liability, especially the car insurance not left a wide field to apply the rules of civil liability. As a result, the system should be considered while return to the past that appointed strict responsibility. One reason for the return was to reduce the claims that were raised due to a large number of the accidents on the trespass. Prove the defendant's fault makes the claim of damage very difficult, while by the implementation of the theory of fault, most of the losses and damages that caused the car accident remained non-compensated due to the difficulty in proving fault and it was the cause that the law of this country gradually returned to the former and insurance became its means (Katouzian \& other, 2002)

In the past, it was said that fault-based liability extensively was for England law and other common law countries. "In the nineteenth century, the principle of "no liability without fault"... in the common law ... was stabilized and widely accepted by lawyers" but gradually deteriorated; however, if it cannot be said that the fault is still the most important basis of responsibility, at least it is one of its two wings and according to the lawyers, separating fault from civic responsibility is not possible (Badini, 2005).

In common law legal system that is based on common law and judicial procedure, the basis of liability should be searched in decisions by the courts but historically, the need for compensation is no based on fault and is observer to compensation. In other words, liability without fault, such as Romano-Germanic legal system is before fault-based liability and fault-based liability was accepted from the late nineteenth century. Now in the legal system, the most important basis for liability is fault, and the majority of judicial decisions issued on this basis, although in some cases, liability without fault is accepted (Soltaninejad. 2015).

According to what has been said above, however, it must be said that in English law (and the laws of America) that is a typical example of common law legal system, civil liability primarily is on the basis of fault, therefore, a set of specific responsibilities, such as trespass, nuisance, defamation are called law of torts (Glannon. 2000)

There is an important issue and noting it is required that by the review of "reckless" or "negligent" cases that are the important foundations in civil liability, we can see that in these cases, liability is based on fault, this is why about responsibility in the law of the country, a basic pattern is provided; this means that the damage must have been caused by the defendant's fault and in addition, one of the kinds of damage of legal responsibilities must be forecasted and identified that appears as:

Act or omission + causation + fault + protected interest + damage $=$ liability. $($ Cooke. 2009)

However, in civil liability, including criminal liability where spiritual element or fault with material element is one of the fundamental elements, fault in Iranian law as well as in English law plays an important role, although by considering texts and ideas of lawyers, it is revealed that nature, basis and role of fault in civil liability law and criminal law have subtle differences (Abdullahi. 2010).

A subject that is very important in English law and many opinions have been issued by it is this that one of the necessary conditions for the realization of fault is that the damage to be predicted. In English law, unlike French law, lawyers believe that in both civil and contractual responsibility, predictability is the condition of claiming damage and to some extent can be claimed for damage that at the time of damage has been predictable for the person causing loss and there is only one difference between the two and that is the damages resulting from the contract is personal criteria, which should be in the realm of compromise for both sides, but in the forcible damage, the human standard is common (Shabiri. 2006).

Here because of the importance of the issue, it would be useful that on the predictability of loss in bodily injuries to express a concept. In the legal system of England, there is a rule that it is called «Thin skull». In fact, this rule is that it should be considered the individual position and what is important is the special situation of suffering even if the agent of damage not to be aware of this issue. (As the extent of the damage need not be foreseeable). Or in other words, this measure is an exception to this rule that kind of a damage that has been achieved to plaintiff should ordinarily be predictable. The cause of naming this exception is that it is said that anyone who hit over another (which, however, has been slow and primarily and traditionally, the man with hitting, the person not to be damaged) but the damaged for reasons as disease of bone (in the way that the bone of head not has the 
ability of resistance against hitting even slow, and breaks) is injured or led to his death that the person who hits is responsible, although such an outcome is not predictable. In other words, if the type of bodily injury is predictable, defendant is liable for compensating all damages even if more than something that has been predicted.

The rule stated exactly is synonymous with another rule that is known as «the eggshell skull rule». This rule is an exception that the type of damage that occurred to plaintiff traditionally is predictable from defendant's fault. In fact, when defendant has conditions that make him more sensitive than a conventional one, the defendant to all damages from his act will have responsibility. In other words, the agent of losing should be considered the victim as it is and not as he has imagined, or known (Stuhmcke. 2001).

About whether it is necessary to be predicted the way of happening damage in the case of bodily injury or not the country's lawyers acknowledge that if the kind of damage is predictable, the way of happening is not required to be predicted (Owen 2000) This is considered in various claims and on the basis of it, the warrant is issued ${ }^{3}$ But $^{2}$ about that the type of damage must be foreseeable or not, in a fight that occurred in $1969^{4}$, was voted that the damage through unclean and dirty food is predictable But that accidentally it leads to a disease that is very rare and is different with type of damage that person is considered or basically occurred is different and therefore was not predictable, the person is not responsible; but years after the country's House of Lords behaved in other way and damage caused by trauma granted to damaged person, although the only physical damage is predictable this means that if he predicted the only bodily injury and not thought that led to psychological damage, he is still responsible for compensation for psychological damage, while the type and nature of the bodily injury is different with trauma. ${ }^{5}$ This procedure was approved and implemented by the appeals court in the country ${ }^{6}$ and where the bodily injury in a car accident is foreseeable, damage over the next psychological damage is covered and compensated and also, the predictability of psychological injuries not needs to be proven (Owen. 2000).

The authors (Stuhmcke. 2001) say that this is not true to say that when assessing whether the defendant has violated its duty or not, talent and readiness of plaintiff (injured) should not be considered and be effective. But when the violation was fixed, and the damage was foreseeable, the defendant must take the victim as they are and will be responsible for the damage, however 'abnormal.' (i.e., in any case that is placed).

As we investigated the impact if this theory in civil liability of compensation for bodily injury In Iranian Law, we examine its effect in English law. First on the Law of England should know a few things: First of all, for someone to be held accountable, it isn't differentiated between misfeasance and nonfeasance, i.e. civil liability includes both, and both can cause damage to the plaintiff (Cooke. 2009). But it is stated that what essentially causes responsibility is misfeasance and nonfeasance in exception cases causes liability like "A" is responsible for guarding the person "B" that is hurt that in this case if the "B" omit the act will be responsible, and act must be tangible and material; But in 1897, in the case discussed in one of the courts of England was voted that immaterial misfeasance could also be considered fault and therefore damage resulting it should be compensated. According to the file, defendant had told as a joke to plaintiff that the person with him in an accident suffered a serious bodily injury and defendant upon hearing the news, was damaged (Soltaninejad. 2001). Second, in English law to be specified the person made fault or no, what is criteria is that how extent the person made the risk. The concept of fault would be non-appropriateness with the ordinary duty of care, which means that person who damages, created such a dangerous state that reasonable person in the normal mode, will never make this state and anyone will be responsible for a certain degree of risk. On the other hand, if someone in the system causes any injury to other, the causal relationship should be proved by suffering. So if a few people shoot someone, but only the shooting of two people injured the other, there is no causal relation between the act of other shooters and bodily injury and they will not be responsible.

But what is the concept of fault? Vinerib writes in the book of thought of private law: in English law for recognizing defendant's fault, we have to use the measure of the risk and not social benefits of his behavior and cost of his care to be the criterion (Badini. 2005). The meaning of this phrase is that fault in the rights of this country is the non-compliance with the criteria of prudence and reasonable care, in which case it is necessary that the person who damages should make a risk that a reasonable person would not make under normal circumstances, in other words, for every human, it is allowed to some extent makes risk and not to be responsible because to the extent, making risk is required for human freedom, but if the risk is predicted for person, he will

\footnotetext{
${ }^{3}$ Hughes v Lord Advocate (1963)

${ }^{4}$ Tremain v Pike

${ }^{5}$ Page v Smith (1995): On the facts of the case, no causal link was established.

${ }^{6}$ Giblett v P and NE Murray Ltd (1999)
} 
be accountable (ibid).

\section{Liability without Fault}

Although in this case that the fault is not the only basis accepted in civil liability, English jurists agree, but what is the basis of responsibility or what is the principle in this case, even there is difference among writers of common law. Some lawyers also have claimed that fault is the only basis on the common law, but others have acted to oppose to this group and reject it. However, the fault is considered one of the principles of civil liability in English law, but not as an absolute issue but in this system, there can be found many cases where liability is without fault that can be referred to the responsibility for keeping dangerous objects that the strict responsibility is accepted, in other words, in some cases, there are instances of civil liability where the fault element is not necessary, i.e. in these cases there is a strict liability, for example, the law requires the employer to his workers use helmet. According to civil liability if the employer violates its legal obligation, ie his workers do not use helmet and leads to body injury, he will be responsible, even if employer uses all his effort for safety of his workers (John Cooke. 2009).

The result that seems to be obtained from this discussion is that in the UK (contrary to Iranian law) cannot identify fault as the general principle of civil liability, although in most cases, even cases of negligence, liability is based on fault. Along the fault, there are other foundations that together make up the country's rights. These include 1) intension 2) strict liability 3) negligence and carelessness (Ghasemzadeh. 2009)

In English law (also in the law of other countries of the common law), theory of without fault left a huge impact and many rules in the process of approving affected by it, but the greatest impact was on laws relating to the sale of goods in general and sell drug products in particular. The rules relating to driving and accidents resulting from it were greatly affected.

In this century in the British court issued several opinions that show the influence of the theory of risk but as mentioned, the principle of liability based on fault and liability without fault is accepted only as exception. In the country, however, from accepting strict liability in events was refused that according to the common law tradition, existing fault is required in them (Eg traffic accidents), but accepted it in actions that have a dangerous nature and imprudence in them will be led to severe physical injury (Badini. 1996).

However, in common law, emphasis is on compensation. "Courts consider establishing peace between the parties and avoiding private revenge more than anything else. It is likely of the beginning; moral concept is in the minds of the judges and has impact in the responsibility but not the main factor. One who by chance or because of his defense wounded the other must compensate the damage. In short, law paid attention to the intention of agent less to the detriment of the injured and the general feeling was that "anyone who breaks shall pay compensation (Katuziyan. 2011).

In the law of the country, although there is a wide variety of claims for civil liability that it is required the fault to be fixed, but there are cases that proving fault is not necessary for them, but it must be proven that the damage is the result of the other side's action, though spiritual element (intent) is not considered to him. Including laws that have been enacted under the influence of liability without fault is Consumer Protection Act 1987. It also can be noted the laws that there is in the field of traffic accidents and compensation for bodily injuries arising from it. It should be noted that in the dispute 7 . In 1994 the House of Lords held that liability without fault onlyis applies where the damages are predictable and strict responsibility for things like harassment only create when the defendant has known orexpected normally expected that they can cause damage. So consumer protection law has appointed a kind of strict liability for manufacturers of defective products causing damage (e.g. bodily injury) to persons (J. Brown. 1999).

\section{Conclusion}

People's civil liability for compensation of damages resulting from bodily injuries has several principles that are the basis of theoretical, juridical and legal. Since in English law, principally there are no theoretical discussions, the topics are discussed and mentioned as the basis that is fully functional, i.e. what happens in practice will be checked and considered the basis. In the legal system that is based on common law and judicial procedure, the basis of liability should be sought on decisions from courts.

Theoretical foundations in the legal system of England also left its impact and in the writings of jurists are analyzed, and liability of without fault is prior on liability based on fault, in the last two centuries, fault-based liability is accepted. Now in the legal system, as far as the theoretical issues are discussed, the most important

${ }^{7}$ Cambridge water co. Ltd V counties leather plc. 
basis for liability is fault, and the majority of judicial decisions issued on the basis, although in some cases, liability without fault is accepted

Neither in Iran's the legal system nor in England cannot be said that one of the basis can be fully accepted and satisfy the needs of civil liability. Of course, the appearance of any of these principles and theoretical issues to achieve and better implementation of the "principle of full compensation for damages" is created, in addition, in terms of each of the damages is compensated more realistically, however, they have drawbacks that each legal system can select and implement based on the case, one as the principal and the rest as subordinate.

\section{References}

Abdullahi, I. (2010). The lessons of the criminal philosophy (Introduction to criminal liability without fault in the legal systems of Iran and the UK) (1st ed.). Tehran, Khorsandi publications.

Badini, H. (2005). Philosophy of civil liability (1st ed.). Tehran, Publishing of Corporation.

Boujnordi, M. M. (2008). Juridical rules (2nd ed., Vol. 1). Tehran, Majd.

Brown, W. J. (1999). GCSE LAW Sweet and Maxwell (7th ed.). London.

Civil Liability Act 1960.

Cooke, J. (2009). Law of tort (9th ed.). London. Pearson Longman.

Deilami, A. (2010). Goodwill in civil liability (1st ed.). Tehran, Mizan.

Elliott, C., \& Quinn, F. (2009). Tort law (7th ed.). London. Pub Pearson Longman.

Farahi, A. (1430 AD). Jurisprudential rule (1st ed.). Qom, Islamic Publishing Institute.

Ghasemzadeh, M. (2004). Fundamentals of civil liability (2nd ed.). Tehran, Mizan publications.

Glannon, J. W. (2000). The law of torts (2nd ed.). New York.

Hekmatnia, M. (2010). Civil liability in jurisprudence (2nd ed.). Qom, Islamic Sciences and Culture Academy.

IPC 1991.

Islamic Penal Code 2013.

Katuziyan, N. (1998). The age of experience of experimental rights, the principle of compensation in the legal system of America. Journal of Law and Political Science, (41).

Katuziyan, N. (2002). Laya Joneidi and Majid Ghamami, civil liability arising from traffic accidents (2nd ed.). Tehran, Tehran University Press.

Katuziyan, N. (2011). Requirements out of the contract (civil liability) (10th ed., Vol. 1). Tehran, Tehran University Press.

Marashi, M. H. (1991, Fall). Blood money and loss caused by the crime. Judicial and Legal journal of Justice, (1).

Mostafavi, M. K. (2011). The rules of jurisprudence 1 (one hundred legal rule), translation of Azizullah Fahimi (1st ed.). Tehran, Mizan publications.

Najafi, M. H. (2005). Javaheralkalam (7th ed., Vol. 42). Tehran, publications of Islamic Darolkotob.

Owen, R. (2000). Essential tort law (3rd ed.). London. Cavendish Publishing Limited.

Pordanjani, A. R. (2013). Criterion of compensation resulting from bodily injury in Iran and England law. Master's thesis of Private Law, University of Qom.

Safai, H., \& Rahimi, H. (2011). Civil liability (mandatory out of the contract) (2nd ed.). Tehran, Samt publications.

Salehi, J. M. (1993). The rights of victims and losses, third party insurance (1st ed.). Tehran, 3. Tehran University Management School Press.

Shabiri, H. V. (2006). The principles of contractual civil liability (the comparative study of law and jurisprudence) (1st ed.). Qom, Islamic Sciences and Culture Academy Press.

Shirazi, N. M. (2011). Rule of the prohibition of detriment (jurisprudential-rule) (1st ed.). (Translation of Seyed Mohammad Javad Saeid Langroodi). Qom, publishing of Imam Ali bin Abi Talib (AS).

Soltaninejad, H. (2001). Civil responsibility for moral damage (1st ed.). Noor Al-Saghalein Press. 
Soltaninejad, H. (2015). Comparative study of moral damages. Publications of Mizan Danesh, Tehran.

Stuhmcke, A. (2001). Essential tort law (2nd ed.). London. Cavendish Publishing.

Tabar, H. J. (1996). Civil liability of manufacturers and sellers of goods (1st ed.). Tehran, Dadgostar publishing.

Zanjani, A. A. A. A. (2003). Causes of liability (Introduction to civil liability and causes and its effects on Islamic jurisprudence (1st ed.). Tehran, Mizan.

\section{Copyrights}

Copyright for this article is retained by the author(s), with first publication rights granted to the journal.

This is an open-access article distributed under the terms and conditions of the Creative Commons Attribution license (http://creativecommons.org/licenses/by/4.0/). 